\title{
Factors in resistance to and recovery from M. pulmonis-induced arthritis in mice
}

\author{
GERALDINE TAYLOR* AND D. TAYLOR-ROBINSON
}

From the MRC Clinical Research Centre, Division of Communicable Diseases, Watford Road, Harrow Middlesex HAI $3 U \mathrm{~J}$

SUMMARY A previous infection of $\mathrm{C} 3 \mathrm{H}$ mice with viable Mycoplasma pulmonis organisms protecte类 them from arthritis induced by intravenous inoculation of these organisms, whether or not theitw initial arthritis had resolved at the time of challenge. Although spleen cells obtained from sucho animals conferred resistance to acute arthritis in syngeneic recipient mice, convalescent-phase serunit was much more effective in this respect. In addition, the transfer of 'immune' spleen cells to M. pulmonis-infected mice treated with cyclophosphamide did not prevent them from dying, whereas the transfer of convalescent-phase serum to such animals reduced the incidence of mortality. Since $M$. pulmonis organisms are rapidly inactivated in mice treated with convalescent-phase serum it if suggested that the transferred serum may act by promoting phagocytosis of the mycoplasmas. Although the reason for some mice developing a prolonged arthritis is not clear, the results show that humoral immune mechanisms are more important than cell-mediated ones in preventing acute arthritis and that the humoral mechanisms are of greater importance than the cell-mediated ino resistance to and recovery from a generalized mycoplasma infection.

Mycoplasmas are known to produce arthritis in a number of animal species (Taylor-Robinson and Taylor, 1976). Some of these infections, such as M. arthritidis in rats (Ward and Cole, 1970), result in an acute, self-limiting arthritis, whereas others, such as $M$. arthritidis in mice (Cole et al., 1971b), M. pulmonis in mice (Barden and Tully, 1969), and M. hyorhinis in pigs (Barden and Decker, 1971), produce a chronic joint inflammation. It has been suggested that the chronicity may be the result of an autoimmune reaction (Harwick et al., 1973) or be due to the persistence of the mycoplasma in a form which provides a continuing stimulus for inflammation.

Some evidence for the latter concept is derived from the fact that mice, which develop a chronic $M$. arthritidis-induced arthritis are less able to control infection by this mycoplasma than are rats which develop an acute disease. Thus, previous inoculation of rats with viable or formalin-inactivated $M$. arthritidis organisms results in complete resistance to a subsequent challenge (Cole et al., 1969), whereas similar attempts to induce immunity

Accepted for publication September 20, 1976

* Present address: ARC Institute for Research on Animal Diseases, Compton, Near Newbury, Berks.

Correspondence to Dr D. Taylor-Robinson to $M$. arthritidis-induced arthritis in mice have beer? only partially successful (Cole et al., 1971a). Furthe $\overline{\overline{0}}$ studies have shown that serum from rats that have recovered from $M$. arthritidis infection prevents disease in recipient animals (Howell and Jones, 1963? Cole and Ward, 1973). On the other hand, serune obtained from previously infected mice confers on recipient animals only partial resistance to disease(Cole et al., 1971a). Thus, the less efficient handling of $M$. arthritidis organisms by mice compared with rats may account for the chronic nature of the disease in the mouse.

Since $M$. pulmonis infection in mice also produce a persistent joint inflammation, which appears to correlate with the presence of mycoplasmas in thes joints (Cole et al., 1975; personal observation), the following investigation was undertaken to determino the extent to which resistance to $M$. pulmonis develops in mice. Further, the relative importance of serum antibody and of cells in resistance to reinfectiofe and in recovery from a primary infection by this mycoplasma was examined.

\section{Materials and methods}

M. PULMONIS

The 'JB' strain of $M$. pulmonis was obtained from? 
Mr. P. C. T. Hannan (Beecham Labs.) as a broth culture, after it had had three in vitro passages from the original provided by Dr. J. G. Tully (NIH, Bethesda, Md., USA). Liquid medium for the isolation and growth of $M$. pulmonis was the same as that described previously (Taylor et al., 1974). Mycoplasmas used to infect mice were grown in thallium-acetate-free medium for about 3 days at $37^{\circ} \mathrm{C}$, dispensed in $1 \mathrm{ml}$ amounts, and stored at $-70^{\circ} \mathrm{C}$. This material was free from bacterial and fungal contamination and contained $10^{8}$ colourchanging units $(\mathrm{ccu}) / \mathrm{ml}$.

\section{MICE}

Male C3H mice, weighing 20-30 g, were supplied by Scientific Agribusiness Consultants (International) Ltd., and by the Animal Division of the Clinical Research Centre (Harrow). The mice were specific pathogen-free, of the MRC Laboratory Animal Centre's category $4(* * * *)$ standard and were still free from detectable mycoplasmas in the nasopharynx at the time of inoculation. Mice were inoculated intravenously (IV) in the tail with $0.2 \mathrm{ml}$ of the M. pulmonis stock pool diluted in PPLO broth. Mice used as uninfected controls were inoculated IV with $0.2 \mathrm{ml}$ of thallium-acetate-free mycoplasma medium. In some experiments animals were inoculated with $M$. pulmonis that had been grown in mycoplasma medium containing $20 \%$ mouse serum instead of horse serum.

\section{CYCLOPHOSPHAMIDE TREATMENT}

A suspension containing $10 \mathrm{mg} / \mathrm{ml}$ of cyclophosphamide (Endoxana, W.B. Pharmaceuticals Ltd.) was prepared in pyrogen-free saline. Mice were injected intraperitoneally with a single dose of 300 $\mathrm{mg} / \mathrm{kg}$ body weight (Poulter and Turk, 1972) 24 hours before infection with M. pulmonis.

\section{ASSESSMENT OF ARTHRITIS}

A subjective assessment of the severity of the arthritis was made by scoring the involvement of each ankle and wrist joint on $a+$ to +++ scale, with erythema and minimal enlargment of a joint being designated + . Scores for groups of mice were added together, divided by the number of animals in each group, and recorded as the arthritis score.

\section{MYCOPLASMA ISOLATION PROCEDURES}

The numbers of mycoplasmas present in various tissues were determined as described previously (Taylor and Taylor-Robinson, 1976). Joints were removed, dissected free from epidermis using aseptic techniques, and cut in half. Both halves were homogenized together in a TenBroek grinder with mycoplasma medium to give a $10 \%(\mathrm{w} / \mathrm{v})$ suspension.
This was regarded as a $10^{-1}$ dilution of the original specimen, and further tenfold dilutions were made from it.

\section{ACTIVE IMMUNIZATION}

Mice were vaccinated by either (1) IV inoculation of a suspension of viable $M$. pulmonis organisms, estimated to contain $2 \times 10^{5} \mathrm{ccu}$ or $2 \times 10^{6} \mathrm{ccu}$, or (b) IV inoculation of a heat-inactivated $\left(56^{\circ} \mathrm{C}\right.$ for $1 \mathrm{~h})$ suspension of organisms, estimated to contain $2 \times 10^{5} \mathrm{ccu}$ or (c) intranasal (IN) inoculation of $5 \times 10^{5}$ or $5 \times 10^{6} \mathrm{ccu}$ of viable organisms. As controls, mice were inoculated with thallium-acetatefree mycoplasma medium. 3 weeks after inoculation of heat-inactivated organisms, animals were challenged IV with $2 \times 10^{5} \mathrm{ccu}$ of $M$. pulmonis. 10 to 14 weeks after IV or IN inoculation of viable organisms mice were challenged IV with $2 \times 10^{6} \mathrm{ccu}$ of M. pulmonis.

\section{PASSIVE IMMUNIZATION}

Spleen cells and sera were obtained from donor mice at various intervals after they had been inoculated IV with $2 \times 10^{6} \mathrm{ccu}$ of $M$. pulmonis as described elsewhere (Taylor and Taylor-Robinson, 1976). Recipient mice received IV either $10^{8}$ viable nucleated cells or $0.25 \mathrm{ml}$ of serum, and they were challenged IV 24 hours later with $2 \times 10^{5} \mathrm{ccu}$ of $M$. pulmonis.

\section{ABSORPTION OF IMMUNE SER UM}

This was done by mixing $4 \mathrm{ml}$ of serum with $300 \mathrm{mg}$ of a washed pellet of either M. pulmonis or M. capri and keeping the suspension for 24 hours at $4^{\circ} \mathrm{C}$, with occasional shaking. The organisms were then separated from the serum by centrifugation at $27000 \mathrm{~g}$ for 20 minutes and the absorption procedure was repeated. Before injection into mice, absorbed serum was examined for the presence of viable mycoplasmas. All sera were sterile.

\section{COMPLEMENT-FIXATION (CF) TEST}

The titre of antibodies to $M$. pulmonis in sera from infected mice was determined by using a previously described microtechnique modification (Taylor and Taylor-Robinson, 1976) of the CF test of Bradstreet and Taylor (1962).

\section{Results}

M. PULMONIS-INDUCED ARTHRITIS IN ACTIVELY IMMUNIZED MICE

In contrast to mice which had received mycoplasma medium or inactivated mycoplasmas, those which had been inoculated IV with viable organisms were protected completely against arthritis produced by subsequent IV challenge (Table 1). Similarly, mice 
Table 1 Effect of active immunization on development of arthritis in mice 14 days after IV challenge with $2 \times 10^{6} \mathrm{ccu}$ of $\mathrm{M}$. pulmonis

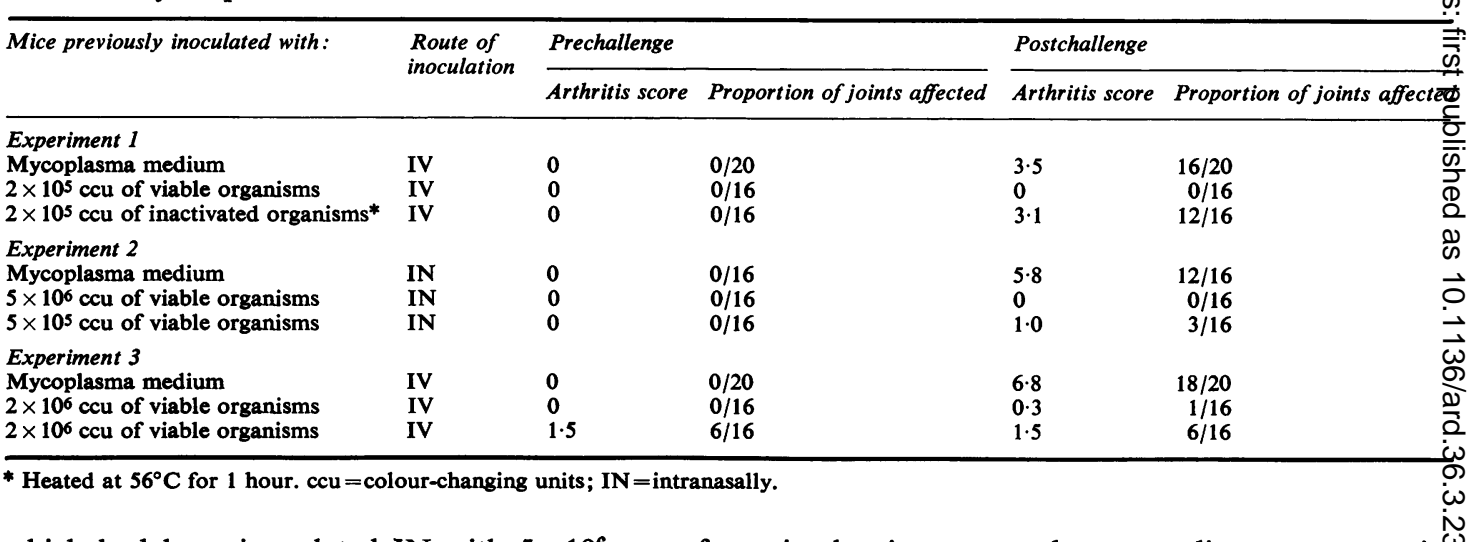

which had been inoculated IN with $5 \times 10^{6} \mathrm{ccu}$ of M. pulmonis were also protected completely against subsequent IV challenge, and only 1 of 4 mice that had been inoculated IN with a tenfold smaller dose developed arthritis after challenge.

The arthritis of all the mice previously inoculated with viable organisms had completely resolved when they were challenged 14 weeks later. If the chronic arthritis is due to inefficient handling of mycoplasmas by the mice, so that they persist in the joints (Cole et al., 1971a), then mice which have not recovered from their arthritis may behave differently from those animals with no residual joint inflammation when challenged. Thus, 8 mice were inoculated IV with $2 \times 10^{6} \mathrm{ccu}$ of $M$. pulmonis and 5 with mycoplasma medium. 10 weeks later, 4 of the previously infected mice which had completely recovered from the arthritis and 4 which still had joint inflammation, were challenged IV with a further $2 \times 10^{6} \mathrm{ccu}$ of M. pulmonis. After challenge, all 5 of the control animals previously inoculated with mycoplasma medium developed a severe arthritis. In contrast, only one of the mice in which arthritis had completely resolved at the time of challenge developed a slight transient arthritis. In addition there was no development or exacerbation of disease in those animals with residual joint inflammation at the time of challenge (Table 1).

\section{PULMONIS-INDUCED ARTHRITIS IN PASSIVELY IMMUNIZED MICE}

(i) Passive transfer of cells

The development of arthritis in mice which had been passively immunized with spleen cells obtained from animals at various intervals after IV inoculation of $2 \times 10^{6} \mathrm{ccu}$ of $M$. pulmonis is shown in Fig. 1. After IV challenge with $2 \times 10^{5} \mathrm{ccu}$ of $M$. pulmonis, the development of arthritis in mice that had been inoculated previously with spleen cells from donor animals given mycoplasma medium was not sigu nificantly different from that in untreated mice (Table 2). Cells obtained from donors 14, 21, and 42 days after infection did provide some protection The mean maximum arthritis scores of groups of mice passively immunized with these cells were significantly less than that of a control group of animals $(P=0.001-0.01,0.001-0.01$, and $<0.001$, respectively; Student's ' $t$ ' test). Furthermore, the numbers of swollen joints observed in mice treates with cells taken from donors 21 and 42 days afteo inoculation were significantly less than in controo animals $\left(P=0.05-0.1\right.$ and 0.01 , respectively; $\chi \frac{2}{2}$ test).

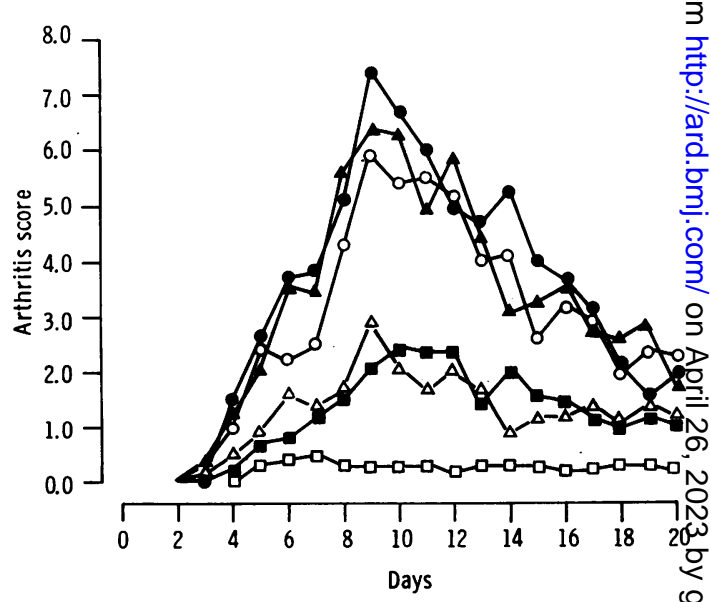

Fig. 1 Effect of passively transferred cells on the development of arthritis in mice inoculated IV with $2 \times 10^{5} \mathrm{ccu}$ (colour changing-units) of $\mathrm{M}$. pulmonis. Cells were obtained from mice inoculated 42 days previously with mycoplasma medium $\bullet$, and from mice inoculated 3 days 0,7 days $\Delta, 14$ days $\triangle, 21$ days $\square$, and 42 days $\square$, previously with $2 \times 10^{6} \mathrm{ccu}$ of $\mathrm{M}$. pulmonis. 
Table 2 Effect of passively transferred cells on the development of arthritis in mice after IV inoculation of $2 \times 10^{5}$ ccu of $\mathrm{M}$. pulmonis

\begin{tabular}{|c|c|c|c|c|}
\hline $\begin{array}{l}\text { Cells for transfer obtained } \\
\text { from mice at indicated days } \\
\text { after IV inoculation of }\end{array}$ & $\begin{array}{l}\text { Day of onset of arthritis } \\
(\text { mean } \pm S D)\end{array}$ & $\begin{array}{l}\text { Maximum arthritis score } \\
(\text { mean } \pm S D)\end{array}$ & $\begin{array}{l}\text { Day of maximum arthritis } \\
(\text { mean } \pm S D)\end{array}$ & Proportion of joints affected \\
\hline 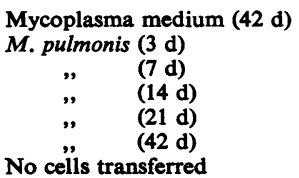 & $\begin{array}{l}5 \cdot 2 \pm 0 \cdot 7 \\
4 \cdot 0 \pm 1 \cdot 0 \\
4 \cdot 2 \pm 0 \cdot 8 \\
6 \cdot 0 \pm 2 \cdot 3 \\
8 \cdot 5 \pm 7 \cdot 0 \\
5 \cdot 0 \pm 0 \cdot 0 \\
4 \cdot 0 \pm 0 \cdot 0\end{array}$ & $\begin{array}{l}7 \cdot 3 \pm 3 \cdot 3 \\
6 \cdot 6 \pm 2 \cdot 2 \\
7 \cdot 8 \pm 1 \cdot 8 \\
4 \cdot 0 \pm 0 \cdot 6 \\
3 \cdot 3 \pm 1 \cdot 3 \\
0 \cdot 5 \pm 1 \cdot 1 \\
8 \cdot 1 \pm 1 \cdot 9\end{array}$ & $\begin{array}{r}12 \cdot 2 \pm 2 \cdot 9 \\
9 \cdot 4 \pm 0 \cdot 5 \\
10 \cdot 2 \pm 2 \cdot 2 \\
9 \cdot 6 \pm 2 \cdot 6 \\
13 \cdot 3 \pm 5 \cdot 3 \\
7 \cdot 0 \pm 0 \cdot 0 \\
9 \cdot 7 \pm 1 \cdot 2\end{array}$ & $\begin{array}{r}16 / 20 \\
16 / 20 \\
19 / 20 \\
13 / 20 \\
10 / 20 \\
2 / 20 \\
19 / 20\end{array}$ \\
\hline
\end{tabular}

(ii) Passive transfer of sera

(a) Effect on arthritis. The development of arthritis in mice passively immunized with various convalescent-phase sera is shown in Fig. 2. Table 3 shows that the proportion of swollen joints in mice treated with sera obtained from animals inoculated 42 days previously with mycoplasma medium was less than in untreated mice $\left(\mathrm{P}=0.02-0.05 ; \chi^{2}\right.$ test $)$. Therefore, the mice treated with sera obtained from animals inoculated with medium were used as controls. In comparison with these control animals, mice which had received sera from donors inoculated IV 7,14 , 21 , and 42 days previously with $M$. pulmonis were significantly protected against arthritis $(\mathrm{P}=0.05-0 \cdot 1$, $0.02-0.05,<0.001$, and $<0.001$, respectively; $\chi^{2}$ test).

(b) Effect on the isolation of M. pulmonis from various tissues. Mice which had been inoculated IV with $0.4 \mathrm{ml}$ of 21-day convalescent-phase mouse serum and untreated mice were inoculated IV 24 hours later with $2 \times 10^{6} \mathrm{ccu}$ of $M$. pulmonis. Groups of 4 mice were sacrificed 24, 48, and 96 hours thereafter and blood samples, spleens, and joints were examined for mycoplasmas. Organisms were not isolated from mice that had been treated with 'immune' serum with the exception of one animal, from which $10^{3} \mathrm{ccu}$ of $M$. pulmonis were isolated from the spleen 48 hours after mycoplasma inocula- tion (Table 4). In comparison, $M$. pulmonis organisms were isolated from all untreated mice and from nearly all the anatomical sites examined.

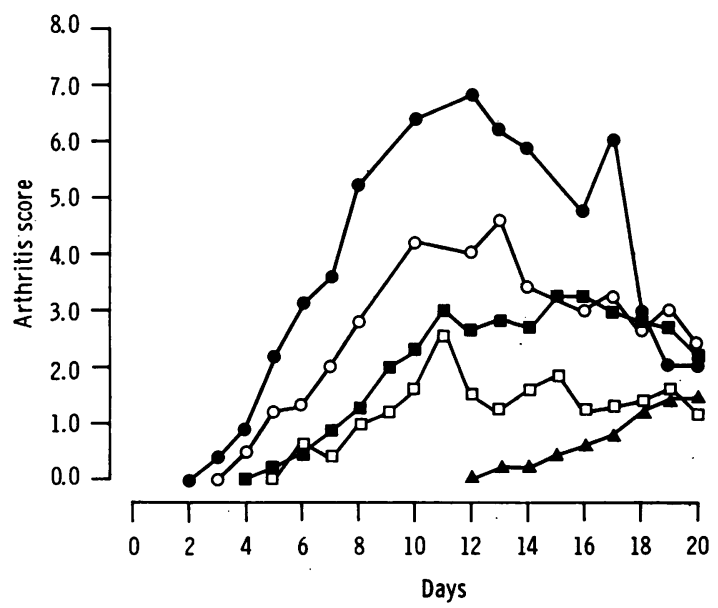

Fig. 2 Effect of passively transferred sera on the development of arthritis in mice inoculated IV with $2 \times 10^{5}$ ccu of M. pulmonis. Sera were obtained from untreated mice $\bullet$, from mice inoculated 42 days previously with mycoplasma medium 0 , and from mice inoculated 3 days $\square, 7$ days $\square$, and 14 days $\Delta$, previously with $2 \times 10^{6} \mathrm{ccu}$ of $\mathrm{M}$. pulmonis.

Table 3 Effect of passively transferred sera on the development of arthritis in mice after IV inoculation of $2 \times 10^{5}$ ccu of $\mathrm{M}$. pulmonis

\begin{tabular}{|c|c|c|c|c|}
\hline $\begin{array}{l}\text { Serum for transfer obtained } \\
\text { from mice at indicated days } \\
\text { after IV inoculation of }\end{array}$ & $\begin{array}{l}\text { Day of onset of arthritis } \\
\text { (mean } \pm S D)\end{array}$ & $\begin{array}{l}\text { Maximum arthritis score } \\
(\text { mean } \pm S D)\end{array}$ & $\begin{array}{l}\text { Day of maximum arthritis } \\
\text { (mean } \pm S D)\end{array}$ & Proportion of joints affected \\
\hline 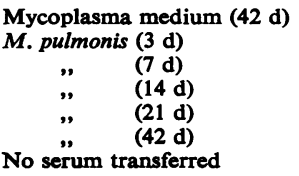 & $\begin{array}{l}5 \cdot 2 \pm 1 \cdot 1 \\
7 \cdot 6 \pm 2 \cdot 4 \\
6 \cdot 0 \pm 0 \cdot 0 \\
15 \cdot 5 \pm 3 \cdot 5 \\
0 \\
0 \\
4 \cdot 0 \pm 0 \cdot 0\end{array}$ & $\begin{array}{l}4 \cdot 8 \pm 1 \cdot 8 \\
4 \cdot 4 \pm 2 \cdot 5 \\
2 \cdot 6 \pm 3 \cdot 1 \\
1 \cdot 5 \pm 2 \cdot 4 \\
0 \\
0 \\
8 \cdot 1 \pm 1 \cdot 9\end{array}$ & $\begin{array}{l}11 \cdot 8 \pm 2 \cdot 7 \\
15 \cdot 0 \pm 4 \cdot 2 \\
10 \cdot 7 \pm 0 \cdot 6 \\
19 \cdot 0 \pm 2 \cdot 4 \\
0 \\
0 \\
9 \cdot 7 \pm 1 \cdot 2\end{array}$ & $\begin{array}{r}12 / 20 \\
10 / 20 \\
6 / 20 \\
4 / 20 \\
0 / 20 \\
0 / 20 \\
19 / 20\end{array}$ \\
\hline
\end{tabular}


Table 4 Effect of 'immune' serum on the isolation of mycoplasmas from mice inoculated IV with $2 \times 10^{6} \mathrm{ccu}$ of M. pulmonis

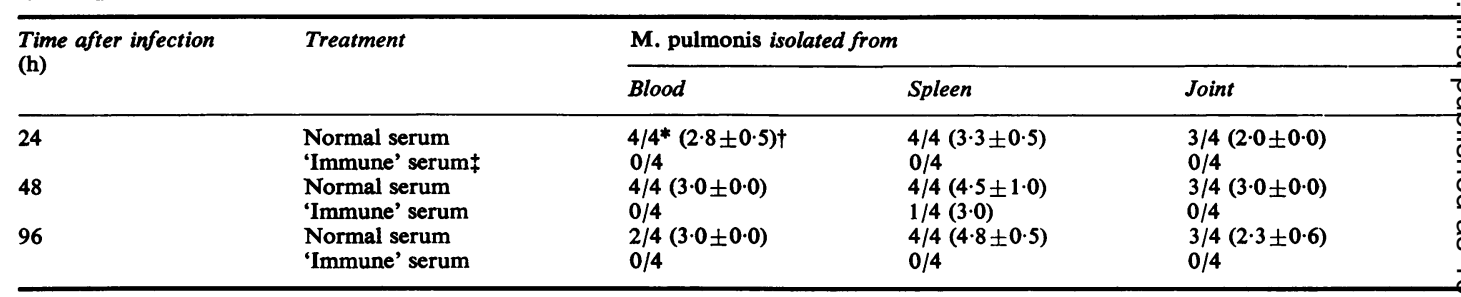

* Proportion of mice from which $M$. pulmonis was isolated.

$\dagger$ Geometric mean of number of organisms isolated, expressed as $\log _{10} \mathrm{ccu} / \mathrm{ml} \pm$ standard deviation.

‡ 'Immune' serum obtained from mice inoculated IV with $M$. pulmonis 21 days previously.

(c) Absorption of 'immune' serum. Serum obtained from mice 21 days after IV inoculation of $2 \times 10^{6} \mathrm{ccu}$ of $M$. pulmonis had an homologous CF antibody titre of $1 / 64$. Absorption of this serum with $M$. pulmonis reduced the CF antibody titre to $1 / 8$, whereas absorption with $M$. capri did not affect the titre. Mice, in groups of 10 , were each treated with $0.4 \mathrm{ml}$ of either 'normal' mouse serum, 'immune' mouse serum, or 'immune' serum absorbed with $M$. pulmonis or $M$. capri. All animals were challenged 24 hours later with $2 \times 10^{6} \mathrm{ccu}$ of $M$. pulmonis organisms which had been grown in medium containing $20 \%$ mouse serum. These organisms were used to challenge the passively immunized mice in an attempt to overcome the slight protective effect observed with serum obtained from mice inoculated with mycoplasma medium which contained horse serum. Arthritis occurred in all mice treated with 'normal' serum, whereas none of the mice that had received 'immune' serum, whether or not it had been absorbed, developed arthritis.

\section{EFFECT OF PASSIVE IMMUNIZATION ON}

SURVIVAL OF CYCLOPHOSPHAMIDE (CY)-TREATED MICE INFECTED WITH M. PULMONIS

Cyclophosphamide treatment of mice inoculated IV with $M$. pulmonis is known to cause a lethal infection (Taylor et al., 1974). The mice appear to have an overwhelming mycoplasma infection suggesting that CY impairs those host defence mechanisms concerned in recovery. In order to determine the immune mechanisms involved in recovery from M. pulmonis infection, the effect of selectively restoring the immune functions of $\mathrm{CY}$-treated mice with serum antibody or sensitized spleen cells was examined.

Groups of 5 mice were treated by $\mathrm{CY}$ and inoculated IV 24 hours later with $2 \times 10^{5} \mathrm{ccu}$ of $M$. pulmonis. 24 hours after infection the mice were inoculated IV with either $0.25 \mathrm{ml}$ of normal mouse serum without detectable CF antibody to $M$. pulmonis, or $0.25 \mathrm{ml}$ of convalescent mouse serumi having a CF antibody titre of $1 / 64$, or $10^{8}$ syngeneit normal spleen cells, or $10^{8}$ syngeneic immunev spleen cells. Normal cells and serum were obtaine\& from mice that had been inoculated IV 3 weeks previously with mycoplasma medium, and immune cells and serum were obtained from mice inoculate IV 3 weeks previously with $2 \times 10^{6} \mathrm{ccu}$ of $M_{0}$ pulmonis. The effect that the various passive immunization procedures had on the survival of CY-treated, infected mice is shown in Fig. 3. Onlo 'immune' serum provided any protection from the lethal infection.

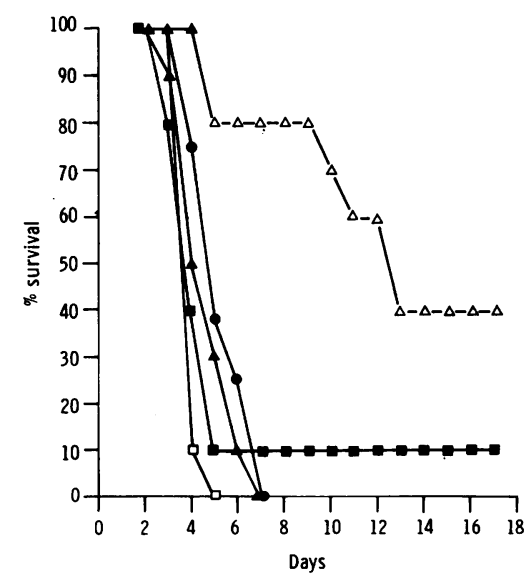

Fig. 3 Effect of 'immune' cells (A), 'immune' serum $(\triangle)$, 'normal' cells $(\square)$, and 'normal' serum $(\square)$, on the survival of mice treated with cyclophosphamide and inoculated IV with $2 \times 10^{5} \mathrm{ccu}$ of $\mathrm{M}$. pulmonis (M. pulmonis + cyclophosphamide only ๑).

\section{Discussion}

The failure to induce resistance to arthritis in mi@e by inoculating them IV with inactivated M. pulmon 
may have been due to administration of too small a dose of mycoplasmas. Certainly, previous inoculation with viable $M$. pulmonis organisms, which have the opportunity of multiplying, prevented mice from developing a renewed arthritis after a subsequent IV challenge of mycoplasmas, whether or not their original arthritis had resolved at the time of challenge. Thus it seems that $M$. pulmonis behaves differently from $M$. arthritidis since Cole et al. (1971a) found that mice developed a mild arthritis after challenge with viable $M$. arthritidis, whether or not their original arthritis had completely resolved.

Since immunization with viable $M$. pulmonis organisms prevented mice from developing arthritis, spleen cells and sera from such animals were examined for their ability to confer resistance to disease on recipient mice. Spleen cells obtained from previously infected donor mice at least partially prevented recipient animals from developing arthritis. This may have been due to the continued production of antibody by the transferred spleen cells. Humoral antibody certainly seems to be important since serum obtained from previously infected animals was much more effective than cells in conferring resistance. Furthermore, the ability of convalescent-phase serum to protect recipient animals from arthritis increased with time after infection of the donor mice. However, the way in which serum exerts its protective effect is not clear and indeed there is no evidence at the moment that it is due to immunoglobulins. Thus, the protective capacity of the serum does not correlate with the presence of CF antibody, since absorption with $M$. pulmonis organisms reduced the CF antibody titre eightfold, but had no demonstrable effect on the capacity of the serum to prevent arthritis in recipient mice.

We have noted this apparent inability of absorption to alter the protective properties of convalescentphase serum during experiments concerned with the prevention of $M$. pulmonis-induced pneumonia in mice (Taylor and Taylor-Robinson, 1976) and it has also been noted by Cole et al. (1969) in experiments on rats which had been passively immunized with sera obtained from animals infected with $M$. arthritidis. These workers also failed to find a correlation between the level of CF antibodies to $M$. arthritidis in rats and mice and resistance to reinfection. lt is possible that the protective factor is directed not against the mycoplasma itself but against some product of it so that the ability of the serum to protect would not be influenced by absorption with whole organisms.

The failure to isolate mycoplasmas from various tissues of mice that had received convalescent-phase sera before IV challenge with $M$. pulmonis suggests that the organisms were rapidly inactivated. Mycoplasma metabolism- or growth-inhibiting antibody, which might be considered important in this respect is present in low or undetectable levels in the sera of mice infected with $M$. pulmonis (Cole et al., 1970; Cole et al., 1975), and also in the sera of rats and mice infected with $M$. arthritidis (Cole et al., 1970, 1976). However, it is possible that inactivation occurs not as a result of a direct action of antibody on the organism, but as a result of phagocytosis. This idea is strengthened by the finding that convalescent mouse serum promotes phagocytosis of M. pulmonis by both mouse macrophages and polymorphs in vitro (G. Taylor, C. J. Howard, and R. N. Gourlay, personal observations).

The finding that the lethal effects of $\mathrm{CY}$ in mice infected with $M$. pulmonis were reversed by the passive transfer of convalescent serum but not by spleen cells suggests that antibody is a critical factor in recovery from infection. Although transferred spleen cells from previously infected mice would probably be producing antibody to $M$. pulmonis; it seems that antibody was not produced rapidly enough to prevent the lethal infection. This is in contrast to the findings of Singer et al. (1972) who reported that the lethal infection produced by intranasal inoculation of $M$. pulmonis in CY-treated mice could be reversed by 'immune' spleen cells. However, these workers did not investigate the effects of passively transferred serum and further, the timing of CY-treatment in relation to passive immunization with spleen cells was different from that reported in this study.

It appears therefore that humoral immune mechanisms are more important than cell-mediated ones both in resistance to and in recovery from a generalized infection with $M$. pulmonis. In the case of arthritis, serum factors either transferred or produced as a result of active immunization are capable of preventing the development of an acute disease presumably because the organisms are not allowed to reach the joints and infect them; the exact mechanism by which the organisms are inactivated is being investigated. The reason why all animals do not recover, the arthritis in some becoming chronic in the presence of a serum factor which is capable of protecting animals against acute arthritis, also requires further study.

\section{References}

Barden, J. A., and Decker, J. L. (1971). Mycoplasma hyorhinis swine arthritis. I. Clinical and microbiologic features. Arthritis and Rheumatism, 14, 193-211.

Barden, J. A., and Tully, J. G. (1969). Experimental arthritis in mice with Mycoplasma pulmonis. Journal of Bacteriology, 100, 5-10. 
Bradstreet, C. M. P., and Taylor, C. E. D. (1962). Technique of complement-fixation test applicable to the diagnosis of virus diseases. Monthly Bulletin of the Ministry of Health, 21, 96-104.

Cole, B. C., and Ward, J. R. (1973). Fate of intravenously injected Mycoplasma arthritidis in rodents and effect of vaccines. Infection and Immunity, 7, 416-425.

Cole, B. C., Cahill, J. F., Wiley, B. B., and Ward, J. R. (1969). Immunological responses of the rat to Mycoplasma arthritidis. Journal of Bacteriology, 98, 930-937.

Cole, B. C., Golightly-Rowland, L., Ward, J. R., and Wiley, B. B. (1970). Immunological response of rodents to murine mycoplasmas. Infection and Immunity, 2, 419-425.

Cole, B. C., Ward, J. R., Golightly-Rowland, L., and Trapp, G. A. (1971a). Chronic proliferative arthritis of mice induced by Mycoplasma arthritidis. II. Serological responses of the host and effect of vaccines. Infection and Immunity, 4, 431-440.

Cole, B. C., Ward, J. R., Jones, R. S., and Cahill, J. F. (1971b). Chronic proliferative arthritis of mice induced by Mycoplasma arthritidis. I. Induction of disease and histopathological characteristics. Infection and Immunity, 4, 344-355.

Cole, B. C., Golightly-Rowland, L., and Ward, J. R. (1975). Arthritis of mice induced by Mycoplasma pulmonis: humoral antibody and lymphocyte responses of CBA mice. Infection and Immunity, 12, 1083-1092.

Cole, B. C., Golightly-Rowland, L., and Ward, J. R. (1976). Arthritis of mice induced by Mycoplasma arthritidis. Humoral antibody and lymphocyte responses of CBA mice. Annals of the Rheumatic Diseases, 35, 14-22.
Harwick, H. J., Kalmanson, G. M., Fox, M. A., and Guze L. B. (1973). Mycoplasmal arthritis of the mouse: develores ment of cellular hypersensitivity to normal synovial tissue: Proceedings of the Society for Experimental Biology ar Medicine, 144, 561-563.

Howell, E. V., and Jones, R. S. (1963). Factors influencin pathogenicity of Mycoplasma arthritidis (PPLOS Proceedings of the Society for Experimental Biology and Medicine, 112, 69-72.

Poulter, L. W., and Turk, J. L. (1972). Proportional increase in the $\theta$-carrying lymphocytes in peripheral lymphofit tissue following treatment with cyclophosphamide. Nature New Biology, 238, 17-18.

Singer, S. H., Ford, M., and Kirschstein, R. L. (1972) Respiratory disease in cyclophosphamide-treated mice. $\$$ Increased virulence of Mycoplasma pulmonis. Infection art Immunity, 5, 953-956.

Taylor, G., and Taylor-Robinson, D. (1976). Effects of actiye and passive immunisation on Mycoplasma pulmonis induced pneumonia in mice. Immunology, 30, 611-618. $\omega$

Taylor, G., Taylor-Robinson, D., and Slavin, G. (1974) Effect of immuno-suppression on arthritis in mice inducep by Mycoplasma pulmonis. Annals of the Rheumat⿱ Diseases, 33, 376-384.

Taylor-Robinson, D., and Taylor, G. (1976). Do mycoplasmas cause rheumatic disease? Infection and Immunology in the Rheumatic Diseases, pp. 177-186. Ed. by D. \& Dumonde. Blackwell, Oxford.

Ward, J. R., and Cole, B. C. (1970). Mycoplasmal infections of laboratory animals. The Role of Mycoplasmas and Forms of Bacteria in Disease, pp. 212-239. Ed. by J. Sharpe. Thomas, Springfield, Illinois. 